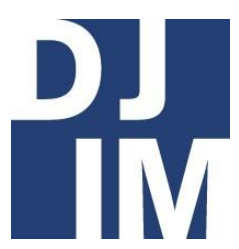

Volume 14

Spring

2018

djim.management.dal.ca |

\title{
Mortgage Lending and Borrowing Regulatory Changes
}

Haydn Mclnroy

School of Business, Dalhousie University

\begin{abstract}
Prices in the Vancouver and Toronto housing markets and increased economic risk are forcing a tightening of mortgage lending across Canada by the Office of the Superintendent of Financial Institutions (OSFI). This form of risk mitigation is carried out through increased stress testing of mortgage borrower income levels along with more strictly enforced loanto-value requirements used to regulate lending practices by Federally Regulated Financial Institutions (FRFIs).
\end{abstract}

The goal of the tightened mortgage lending is due to concerns surrounding the increasingly alarming debt problem as Canadian debt to income levels doubled in the past two decades. As well, there have been historical drops in Debt-Service ratios of Canadians during economic downturn. With Canadian debt to income levels at an all-time high, high levels of mortgage debt that makes up the overall debt of Canadians and higher current Canadian rates relative to the US prior to the 2008 financial crisis, the tightening of mortgage regulations are necessary as a form of economic risk mitigation.

Written in the format of a memorandum to a Deputy Minister in the Department of Finance of the Federal Canadian Government, this paper examines and addresses key issues related to the increased mortgage regulations being carried out by OSFI and the federal government. The research method presentation of the current Canadian real estate market is supported by quantitative analysis, followed by a summary of the regulatory changes proposed by the OSFI, and an analysis of how these changes will impact the market. Based on this research, recommendations directed to a Deputy Minister are consolidated. 
MEMORANDUM TO DEPUTY

MINISTER OF THE DEPARTMENT

OF FINANCE

ECONOMIC RISK MITIGATION

THROUGH REGULATORY CHANGES

TO MORTGAGE CREDIT

\section{EFFECTS OF REGULATORY \\ CHANGES TO CANADIAN ECONOMY AND BORROWERS}

\section{SUMMARY}

Prices in the Vancouver and Toronto housing markets are forcing a tightening of mortgage lending across Canada. This form of risk mitigation is creating other risk management issues.

These could have been avoided by a mandatory stress test of mortgage borrower income levels along with more strictly enforced loan-to-value requirements used to regulate lending practices.

There is a broader debt problem as Canadian debt to income levels has doubled in the past two decades. Regulations are needed to address this issue and will have an impact on the housing market as well.

\section{Introduction}

The Canadian government is changing regulations on home mortgages and loans. It is important to examine how regulations will affect housing markets, Canadian citizens, and the economy. Regulatory changes are due to an increased fear of economic downturns in regional markets, interest rate increases, and the high debt levels of Canadians. As analyzed within this memorandum to the Deputy Minister within the Department of Finance, the increased regulations for mortgage lending and borrowing are being used as a risk mitigation tool by the Canadian government to lower the economic risk created by the increasing debt levels of Canadian citizens.

The increased mortgage credit regulations are an effective economic risk mitigation tool that limits increasing Canadian debt levels driven by mortgage debt, while attempting to deflate increasing economic risk being created within key regional markets in Canada. Overall, these regulations decrease the level of macroeconomic risk and strengthen the Canadian economy by pro-actively addressing Canadian debt levels that are subject to increased risk through rising interest rates, drops in historic debt service ratios in recessionary periods, and limiting the probability of systemic issues similar to those within the US that caused the 2008 financial crisis.

\section{Current Market}

The Toronto Real Estate Board (2017) indicated that the average prices of residential units in Toronto has increased from approximately $\$ 200,000$ in 1995 , to $\$ 775,000$ in 2017 (See Appendix 1). Similarly, in Vancouver, the average prices of single residential units have increased 
from approximately $\$ 400,000$ in 1995 to $\$ 1,501,770$ in 2017, a 274.44\% growth (See Appendix 2) (Real Estate Board of Greater Vancouver, 2017). According to $R B C$ Economics (2017), these markets are above the Canadian average of $\$ 490,600$ (See Appendix 3), and are responsible for forecasted growth in their provincial markets above aggregate Canadian prices, with Ontario and British Columbia markets making up $66 \%$ of all sales of existing residential properties in 2016, while making up $59 \%$ and $56 \%$ of total housing starts in 2016 and 2017 respectively (Jang, 2017; Statistics Canada, n.d.).

There are other economic issues that could affect the Canadian housing market as well. The Bank of Canada raising overnight interest rates from $0.50 \%$ to $1.00 \%$, the highest since the 2008 financial crisis, will affect mortgage rates countrywide and slow spending in real estate (Trading Economics, n.d.). Rising interest rates could lead to pre-2008 interest rate levels that were several times higher than current levels (See Appendix 4) (Trading Economics, n.d.). The overnight rate increases are reflected in increased bank and borrower prime rates and variable rate mortgage costs. Similarly, this also increases fixed income and bond market yields that increase the costs of fixed rate mortgages (Sirmans, Smith, and Sirmans, 2015). Other positive economic factors, such as the decreasing unemployment rate $(5.9 \%$ at the time of publication), creates increased real estate spending, as increasing unemployment rates are negatively Mortgage Lending and Borrowing Regulatory Changes correlated with mortgage credit and services growth (Trading Economics, n.d.; Bates and Santerre, 2016).

With regional bubbles in Vancouver and Toronto, rising interest rates, and high Canadian debt ratios, the Federal Government's regulation of the housing market is critical, as the 2008 financial crisis was caused by the housing market bubbles, deregulation on mortgage lending, securitization of bundled mortgages, and high individual debt levels.

It should be noted that a market bubble is characterized as the inflation of an asset where low risk premiums that are part of the expected return on the asset, lead to an increase in the asset price (Liu, Hiu, Lv, and Chen, 2016). Overall, the perceived low risk of the asset due to the low risk premium leads to increased investment in the asset inflating its price. This is what is happening within the regional bubbles of Toronto and Vancouver, where the low risk and high expected return on real estate investments within the markets continues to drive prices.

Prior to 2008, the United States had regional real estate bubbles fueled by decreasing interest rates that increased demand and prices (Docking, 2011). Coincidently, increased deregulated mortgage credit lending to higher risk individuals became commonplace, referred to as subprime mortgage lending (Spiegel, 2011). For example, $43 \%$ of first-time U.S. home buyers in 2005 used no-moneydown mortgage loans (Docking, 2011). 
Furthermore, debt to income levels among US citizens peaked at $163 \%$ pre-recession (TD Economics, 2013).

Subprime loans were bundled and sold to investment banks who packaged and sold them as mortgage backed securities (MBS) to investors (Docking, 2011). Increased interest rates in 2007 led to the inability of many borrowers to meet principle payments, along with increased difficulty in refinancing loans when housing prices and values decreased, leaving many with negative equity on their homes. For example, homes would appraise for less than the mortgage (Docking, 2011).

When defaults increased, underlying mortgages and home values within MBS left instruments with little value (Docking, 2011). This caused unregulated over-thecounter (OTC) derivative market instruments, which relied on MBS and were guaranteed by American International Group (AIG) and other insurance companies, becoming callable through the required credit event of the MBS derivative. This became a major financial system issue as insurers of MBS derivative transactions did not have enough capital to meet commitments (Docking, 2011).

Therefore, the Office of the Superintendent of Financial Institutions (OSFI) federal regulatory changes look to reduce potential market bubbles caused by mortgage credit and debt levels of Canadians through increased mortgage lending and borrowing regulations. These increased regulations reduce the probability and risk of creating a system similar to that which caused the 2008 financial crisis.

\section{Regulatory Changes}

The Federal Government is attempting to reduce risk in regional housing markets while limiting economic downturn risk by focusing on: (1) financial institutions providing mortgage lending to borrowers, and (2) borrowers themselves. By increasing regulations of mortgages and loans, the government is limiting economic downturn risk through reduced home loan insurance and household debt levels.

OSFI has addressed these issues through Guideline B-20 - Residential Mortgage Underwriting Practices and Procedures, coming into effect January 1, 2018 for federally regulated financial institutions (FRFIs) (Office of the Superintendent of Financial Institutions, 2017).

The B-20 Guideline addresses risk mitigation in three areas:

1. Required income stress tests on borrowers assessing if borrower income levels can withstand economic sensitivities. Homebuyers must prove they can withstand $2 \%$ increase on mortgage rates, both fixed and adjusted regardless of term (Office of the Superintendent of Financial Institutions, 2017).

2. Enhanced Loan-to-Value (LTV) ratio measurements and limits. Limits, that are unique to each FRFI should 
be consistently updated to reflect current loan risk profile, such as refinancing options, market conditions, and "any other relevant risk that may affect the sustainability of the value of the underlying property" (Office of the Superintendent of Financial Institutions, 2017, p. 12).

3. Restricting lending arrangements that circumvent LTV limits by eliminating loopholes used by lenders to provide "bundled" loans or co-lending arrangements. This includes loans that combine debt from regulated and unregulated providers, where consumers may combine various funding sources within a single funding structure secured by the same property (Office of the Superintendent of Financial Institutions, 2017).

Further loophole restrictions focus on mortgage default insurance as a risk mitigation strategy (Office of the Superintendent of Financial Institutions, 2017). According to OSFI, "Mortgage insurance should not be a substitute for sound underwriting practices by FRFIs [...] it should not be considered a substitute for conducting adequate due diligence on the borrower, or for using other risk mitigants" (2017). This refers to the practice of lenders obtaining mortgage insurance from $\mathrm{CMHC}$ or other providers to reduce risk in underwriting. Leading mortgage insurance lender and crown corporation, $\mathrm{CMHC}$, highlights the federal government's goals in reducing its own risk by limiting $\mathrm{CMHC}^{\prime} \mathrm{s}$ risky lending practices, where defaults cause $\mathrm{CMHC}$ and government to pay lending FRFIs.

\section{Analysis}

Household debt levels of Canadians have increased $97.70 \%$ since 1990 at $85.94 \%$ to a high of 169.9\% in 2017 (See Appendix 5) (Statistics Canada, n.d.). This puts the current debt-to-income levels of Canadians as greater than the US debt-to-income ratios that peaked at $163 \%$ prior to the 2008 crisis (TD Economics, 2013). Therefore, this raises the issue of potentially reducing household debt levels through mortgage regulation (See Appendix 5), as mortgage and credit debt make up a substantial portion of overall Canadian household debt and is strongly correlated with overall debt levels (Statistics Canada, n.d.). Over the 1990-2017 period, mortgage and credit debt has increased from making up $89.34 \%$ of overall household debt in Q1 1990, to $93.67 \%$ in Q2 2017 (Statistics Canada, n.d.).

Furthermore, by examining historical Canadian debt service ratios (See Appendix 6), additional economic risk is uncovered (Statistics Canada, n.d.). Decreases in debt service ratio was present during three events: (1) the early 1990s recession, (2) the early 2000s recession, and (3) the 2008 financial crisis. This finding highlights the decreased ability of Canadians to service debt obligations during economic downturns. Therefore, by using OSFI 
regulations to proactively limit Canadian debt levels through reduced mortgage debt, the Canadian government is limiting economic risk though decreasing debt levels that cannot be met in recessionary periods.

However, there are issues with the scope of OSFI regulations. OSFI regulations apply only to FRFIs. B-20 Guidelines are ultra vires in regulating issues related to nonFRFIs, such as provincially regulated credit unions which are the second largest mortgage lenders in Canada, lending approximately $\$ 171,238,000$ in 2015 , $13 \%$ of total residential mortgage credit lending (See Appendix 7 (Canadian Mortgage and Housing Corporation, 2016).

The scope of federal regulations are different than that of the provincial governments of British Columbia and Ontario, who currently have their own regulations. These provincial jurisdiction's regulations focus on domestic and foreign buyers, instead of federal mortgage regulation. In $B C$, the Vancouver market has seen a decrease in the number of foreign buyers investing in the market, with only $4.8 \%$ non-resident ownership of residential properties (Marketline, 2016; Statistics Canada, n.d.). However, the residential properties purchased have an average assessment value of approximately $\$ 1,162,700$, where the foreign investment still continues to price out domestic buyers, resulting in the creation of a 15\% Foreign Buyers Tax for offshore investors (Gellatly and Morissette, 2017; Marketline, 2016).
Similarly, in Ontario, a 15\% tax on foreign residential property investment was enacted, along with the creation of the Ontario Fair Housing Plan in April 2017 focusing on a lower and more regulated pricing system within both real estate and rental markets (Scotiabank Global Economics, 2017).

Therefore, based on the scope of the federal government regulations and jurisdictions, focusing on risk mitigation through addressing national economic risk by limiting debt levels of Canadians, it must be cautious in implementing stronger federal regulations. The potential risk is increased regulation leading to increased difficulty in investing and a downturn in real estate investment. This would slow the Canadian economy as the housing market has historically made up an average of $12.6 \%$ of the Canadian GDP since 2009, with a historical CAGR of 3.2\% over the same period (See Appendix 8) (Statistics Canada, n.d.).

\section{Conclusion}

The new OSFI mortgage credit borrowing and lending regulations put in place by the federal government in January 2018 create a risk mitigation strategy to decrease economic risk through limiting mortgage debt due to its large stake in Canadian debt levels. This alleviates potential economic risk and potential issues that may arise if markets downturn, highlighted by the increasing debt levels of Canadians and the drops in Canadian debt service ratios during recessionary periods. The $B-20$ 
Guidelines are an effective economic risk mitigation tool that will deter economic risk resembling that in the United States prior to 2008. This is achieved primarily through increased borrower income stress tests, stricter LTV measurements and limits, and stricter FRFI lending regulations.

Although regional market bubbles are found within Toronto and Vancouver, the overall federal government jurisdiction is the regulation of overall economic conditions and macroeconomic risk mitigation, with the goal of the $B-20$ Guidelines to decrease risk levels created though increased mortgage debt. Although the increased federal regulation may lead to potential downturn in real estate investing, pro-actively addressing Canadian debt levels and regulating rising issues similar to those responsible for the 2008 financial crisis lowers overall Canadian economic risk. The $B-20$ Guidelines therefore, create a sound regulatory initiative that focuses on overall economic risk factors, while leaving provincial governments to create their own risk mitigation strategies focused on decreasing market bubbles and potentially inflated asset prices though taxing foreign investment and driving domestic real estate investment.

\section{References}

Bates, L. J., \& Santerre, R. E. (2016). The Market Demand Characteristics Associated with Real Estate
Canadian Mortgage and Housing Corporation. (2016, July). CHS: Mortgage Lending 2015.

Docking, D. S. (2011). The 2008 financial crises and implications of the Dodd-Frank Act. Journal of Corporate Treasury Management, 4(4), 353-363.

Gellatly, G., \& Morissette, R. (2017) Nonresident Ownership of Residential Properties in Toronto and Vancouver: Initial Information from the Canadian Housing Statistics Program, Statistics Canada Analytical Studies Branch. Retrieved from:

http://www.statcan.gc.ca/pub/11626-x/11-626-x2017078-eng.htm

Housing and Market Information.

Retrieved from https://www.cmhcschl.gc.ca/odpub/esub/64687/6468 7_2016_A01.pdf?fr $=1511145103591$

Jang, B. (2017, January 16). 2016 was a record-setting year for Canada's housing market. The Globe and Mail. Retrieved from: https://www.theglobeandmail.com/r eport-on-business/2016-was-arecord-setting-year-for-canadashousing-market/article33640396/

Liu, R., Hui, E., Lv, J., \& Chen, Y. (2016). What Drives Housing Markets: Fundamentals or Bubbles? Journal 
of Real Estate Finance \&

Economics, 55: 395-415.

MarketLine. (2016, June 30). Toronto - City Profile. Retrieved from http://advantage.marketline.com.ez proxy.library.dal.ca/Product?ptype= Cities\&pid=ER0046CP

MarketLine. (2016, September 8).

Vancouver - City Profile. Retrieved from

http://advantage.marketline.com.ez proxy.library.dal.ca/Product?ptype= Cities\&pid=ER0047CP

Office of the Superintendent of Financial Institutions. (2013, January). Corporate Governance. Retrieved from http://www.osfibsif.gc.ca/Eng/fi-if/rg-ro/gdn-ort/glId/Pages/CG_Guideline.aspx

Office of the Superintendent of Financial Institutions. (2017, October). OSFI is reinforcing a strong and prudent regulatory regime for residential mortgage underwriting. Retrieved from http://www.osfibsif.gc.ca/Eng/osfibsif/med/Pages/B20_dft_nr.aspx

Office of the Superintendent of Financial Institutions. (2017, October). Residential Mortgage Underwriting Practices and Procedures - effective January 1, 2018. Retrieved from http://www.osfi-bsif.gc.ca/Eng/fi- if/rg-ro/gdn-ort/gl-

Id/Pages/b20_dft.aspx

RBC Economics. (2017, October 17). Canada's Housing Market - As expected, OSFI tightens rules for non-insured mortgages. RBC Economics. Retrieved http://www.rbc.com/economics/eco nomic-reports/pdf/canadianhousing/housing_OSFI_Oct2017.pdf

RBC Economics. (2017, October). Home Resale and Price Forecast - October 2017. RBC Economics. Retrieved http://www.rbc.com/economics/eco nomic-data/pdf/home-resalefcst_can.pdf

Real Estate Board of Greater Vancouver. (February 2017). Metro Vancouver housing market off to a quieter start than last year. Retrieved from: http://www.rebgv.org/sites/default/f iles/2017-01-January-StatsPackage.pdf

Scotiabank Global Economics. (2017, April 20). Ontario's Fair Housing Plan: Multiple Measures with Uncertain Impact. Scotiabank Global Economics. Retrieved from: http://www.gbm.scotiabank.com/sc pt/gbm/scotiaeconomics63/201704-20_I\&V.pdf

Services: Some Evidence from a Panel Data Set of MSAs. Journal of Real 
Estate Finance \& Economics, 53:

77-89.

Sirmans, C. S., Smith, S. D., \& Sirmans, G. S. (2015). Determinants of Mortgage Interest Rates: Treasuries versus Swaps. Journal of Real Estate Finance \& Economics, 50;34-51.

Spiegel, M. (2011, June). The Academic Analysis of the 2008 Financial Crisis: Round 1. Review Of Financial Studies. 24(6):1773-1781

Statistics Canada. (n.d.). Canadian Housing Statistics Program, CANSIM (database). Retrieved March 2, 2018, from: http://www.statcan.gc.ca/dailyquotidien/171219/dq171219beng.ht $m ? \mathrm{HPA}=1$

Statistics Canada. (n.d.). Table 027-0008

- Canada Mortgage and Housing Corporation, housing starts, under construction and completions, all areas, CANSIM (database).

Retrieved March 2, 2018, from: http://www5.statcan.gc.ca/cansim/a 26? lang $=$ eng \& retrLang $=$ eng \&id $=02$ $70008 \& \&$ pattern $=\&$ stByVal $=1 \& p 1=$ $1 \& \mathrm{p} 2=37 \&$ tabMode $=$ dataTable $\&$ csi $d=$

Statistics Canada. (n.d.). Table 378-0123

- National Balance Sheet Accounts, financial indicators, households and non-profit institutions serving households, quarterly

Mortgage Lending and Borrowing Regulatory Changes (percent), CANSIM (database). Retrieved December 5, 2017, from: ttp://www5.statcan.gc.ca/cansim/a2 6 ?lang $=$ eng $\&$ retrLang $=$ eng $\&$ id $=378$ 0123\&\&pattern $=\&$ stByVal $=1 \& p 1=1$ $\& p 2=31 \&$ tabMode $=$ dataTable $\& c s i$ d

Statistics Canada. (n.d.). Table 379-0031

- Gross domestic product (GDP at basic prices, by North American Classification System (NAICS), CANSIM (database). Retrieved March 2, 2018, from: http://www5.statcan.gc.ca/cansim/a 37

Statistics Canada. (n.d.). Table 380-0073

- Selected indicators - Households, quarterly (dollars unless otherwise noted), CANSIM (database).

Retrieved from: http://www5.statcan.gc.ca/cansim/a 26? lang $=$ eng \& id $=3800073$

TD Economics. (2013, July 16). Canadian households more indebted than U.S. Households, but only after the recent U.S. deleveraging. TD Economics. Retrieved from https://www.td.com/document/PDF /economics/special/CanadianHouse holdDebt.pdf

Toronto Real Estate Board. (October 2017). TREB Housing Market Charts October 2017. Retrieved from 
http://www.trebhome.com/market_ news/housing_charts/index.htm

Trading Economics. (n.d.). Canada Interest Rate. Retrieved December 5, 2017, from

https://tradingeconomics.com/cana

da/interest-rate
Trading Economics. (n.d.). Canada

Unemployment Rate. Retrieved

December 5, 2017, from

https://tradingeconomics.com/cana

da/unemployment-rate 


\section{Appendices}

\section{Appendix 1 - Toronto Housing Prices 1995-2017}

\section{1) Reronto

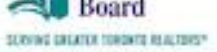

\section{TREB Housing Market Charts}

TREB $\mathrm{MLS}^{\odot}$ Average Price

Monthly Time Series with Trend Line

975,000
875,000
775,000
675,000
575,000
475,000
375,000
275,000
175,000

- Actual MLS ${ }^{\odot}$ Average Price

-Trend (12-Month Moving Average)

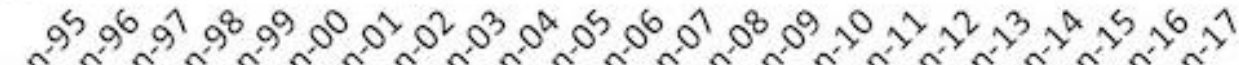

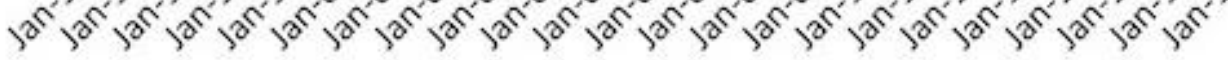

Appendix 2 - Vancouver Housing Prices 1977-2017

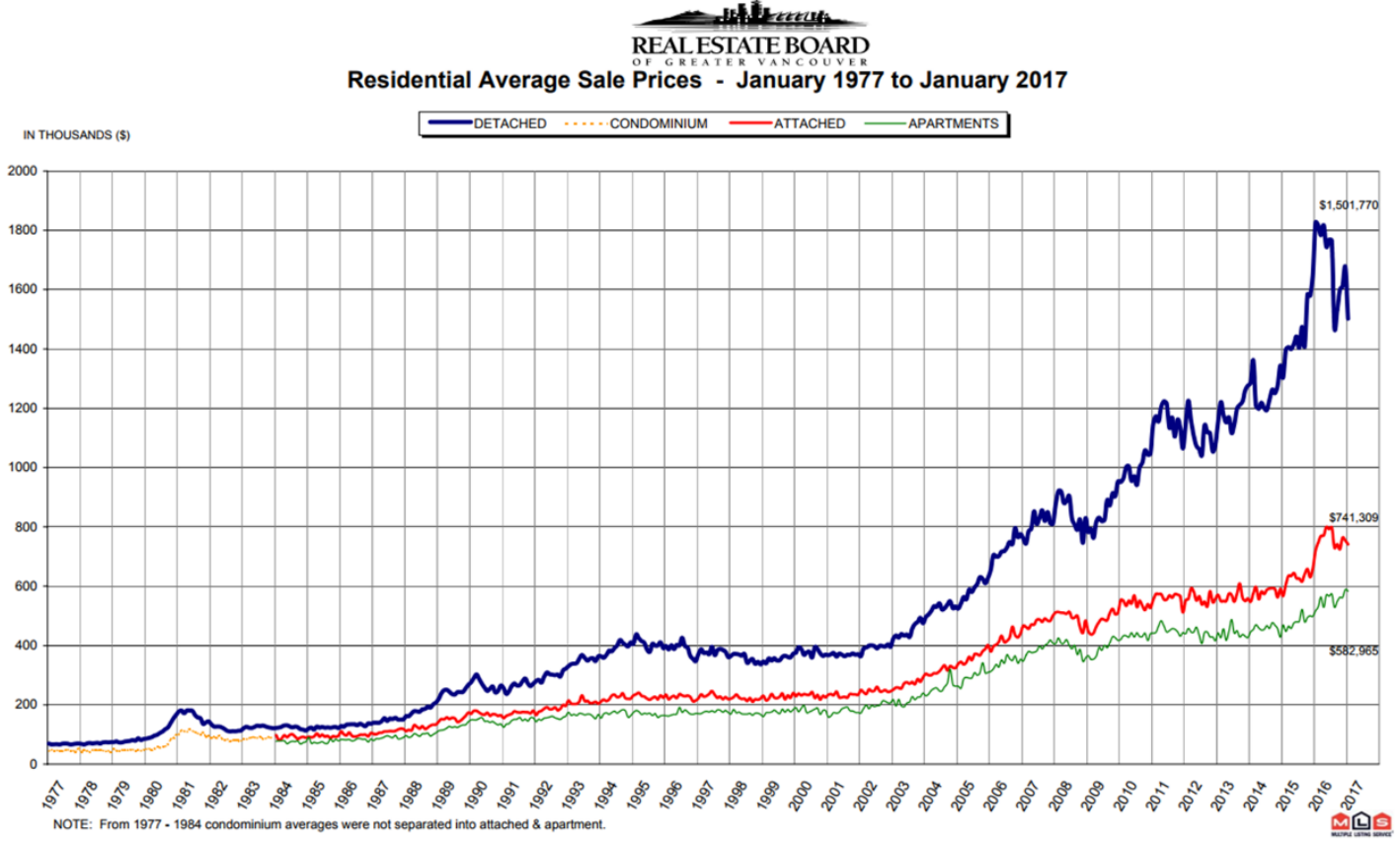


Appendix 3 - Canadian, Ontario, and British Columbia Historic and Forecasted Average Housing Prices

Canadian Home Historical and Forecasted Prices RBC Economics

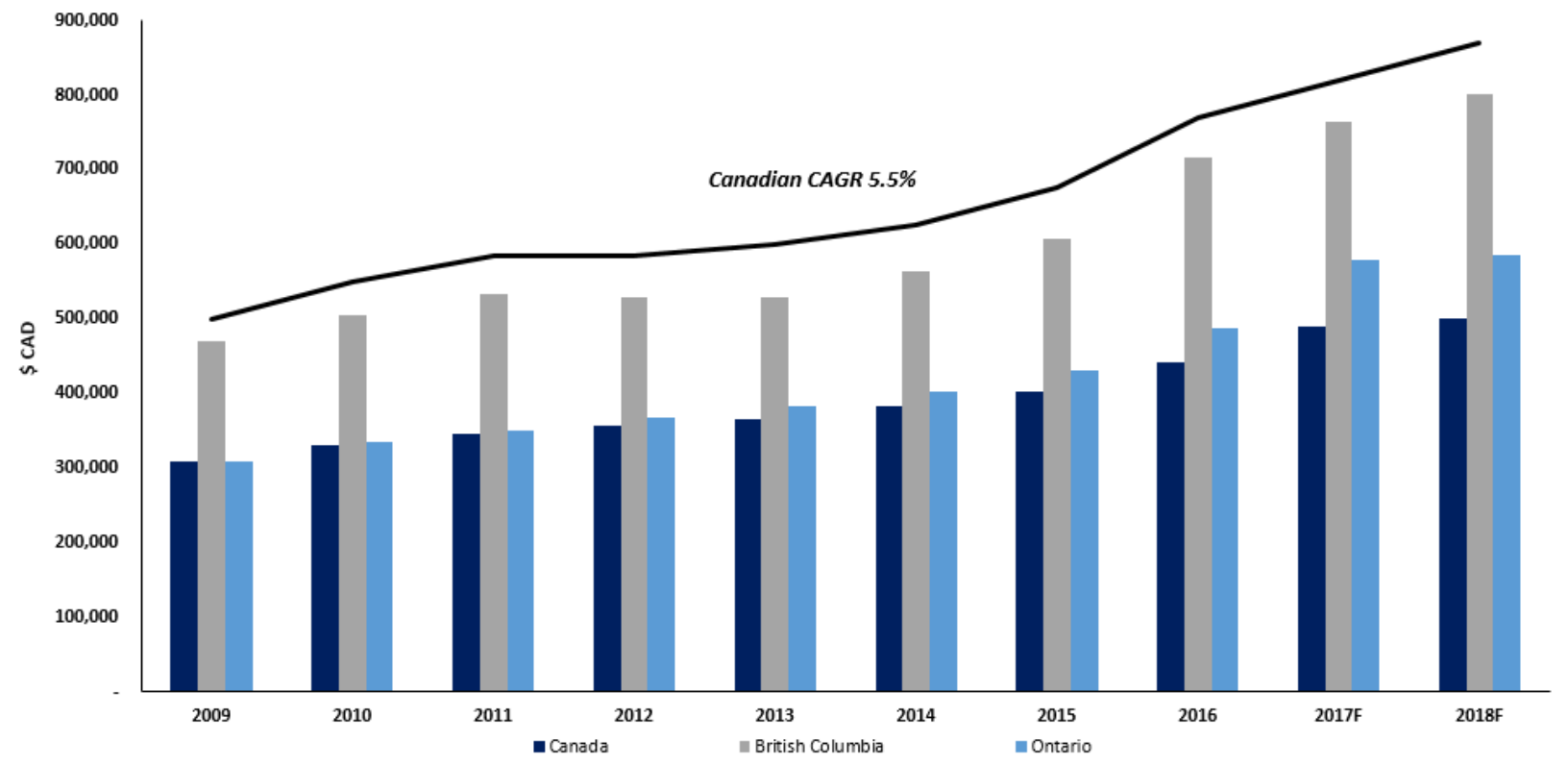

Appendix 4 - Canadian Overnight Interest Rate 1990 - 2017

CANADA INTEREST RATE

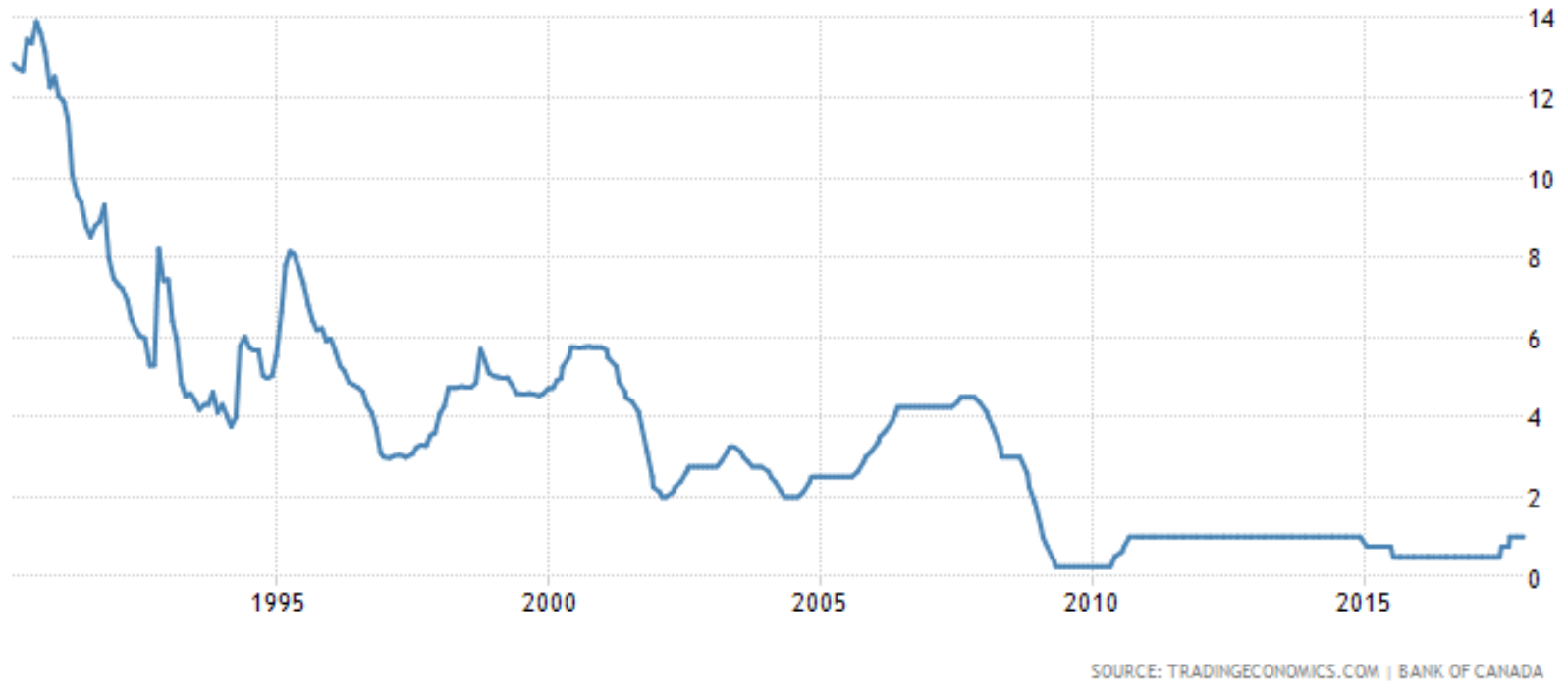


Appendix 5 - Canadian Household and Mortgage Debt to Disposable Income 1990 2017

Canadian Household Debt and Mortgage Debt to Disposable Income 1990 - 2017 Q2

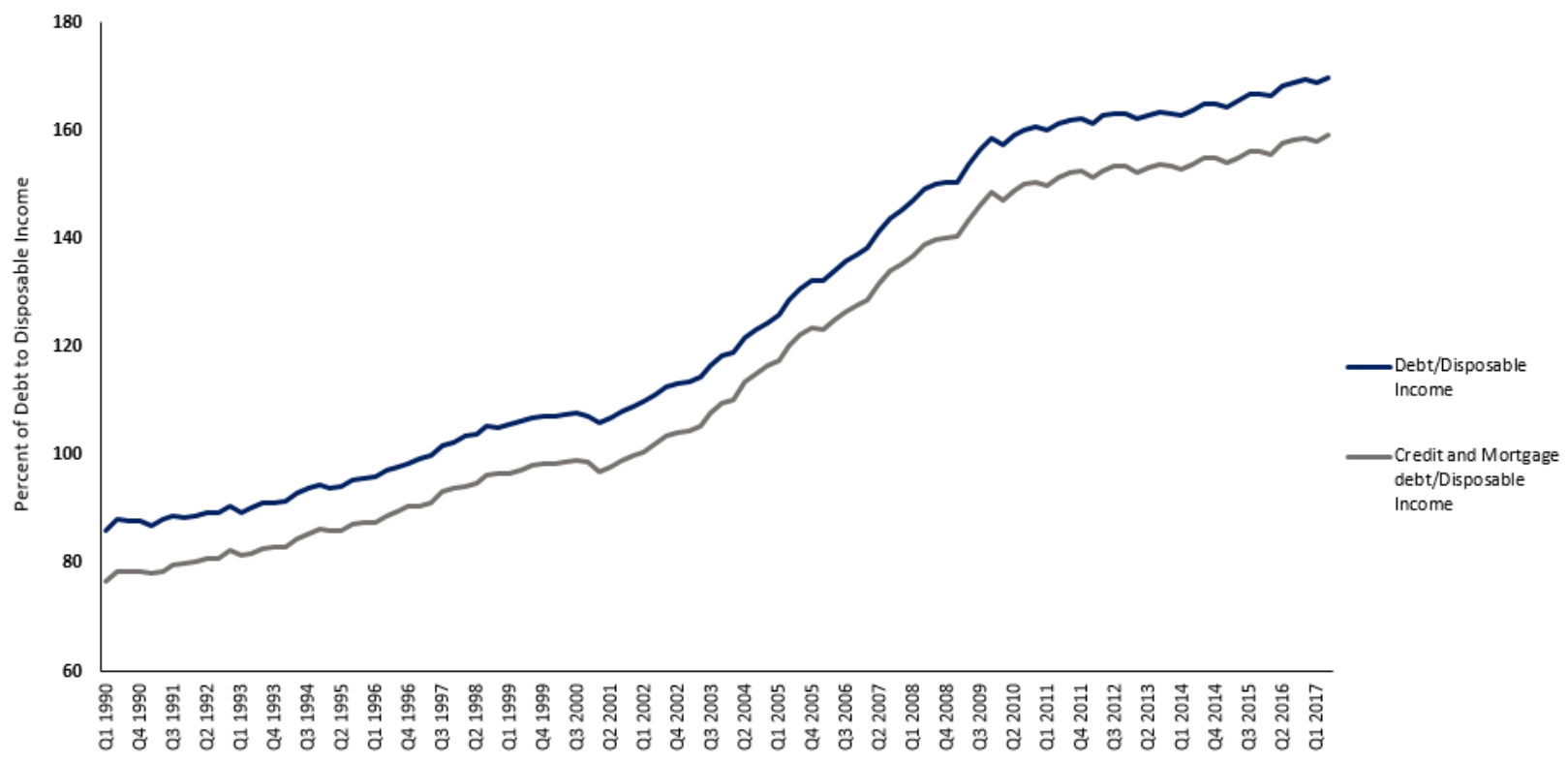

Appendix 6 - Canadian Debt Service Ratio 1990 - 2017

Canadian Debt Service Ratio 1990 - 2017 Q2

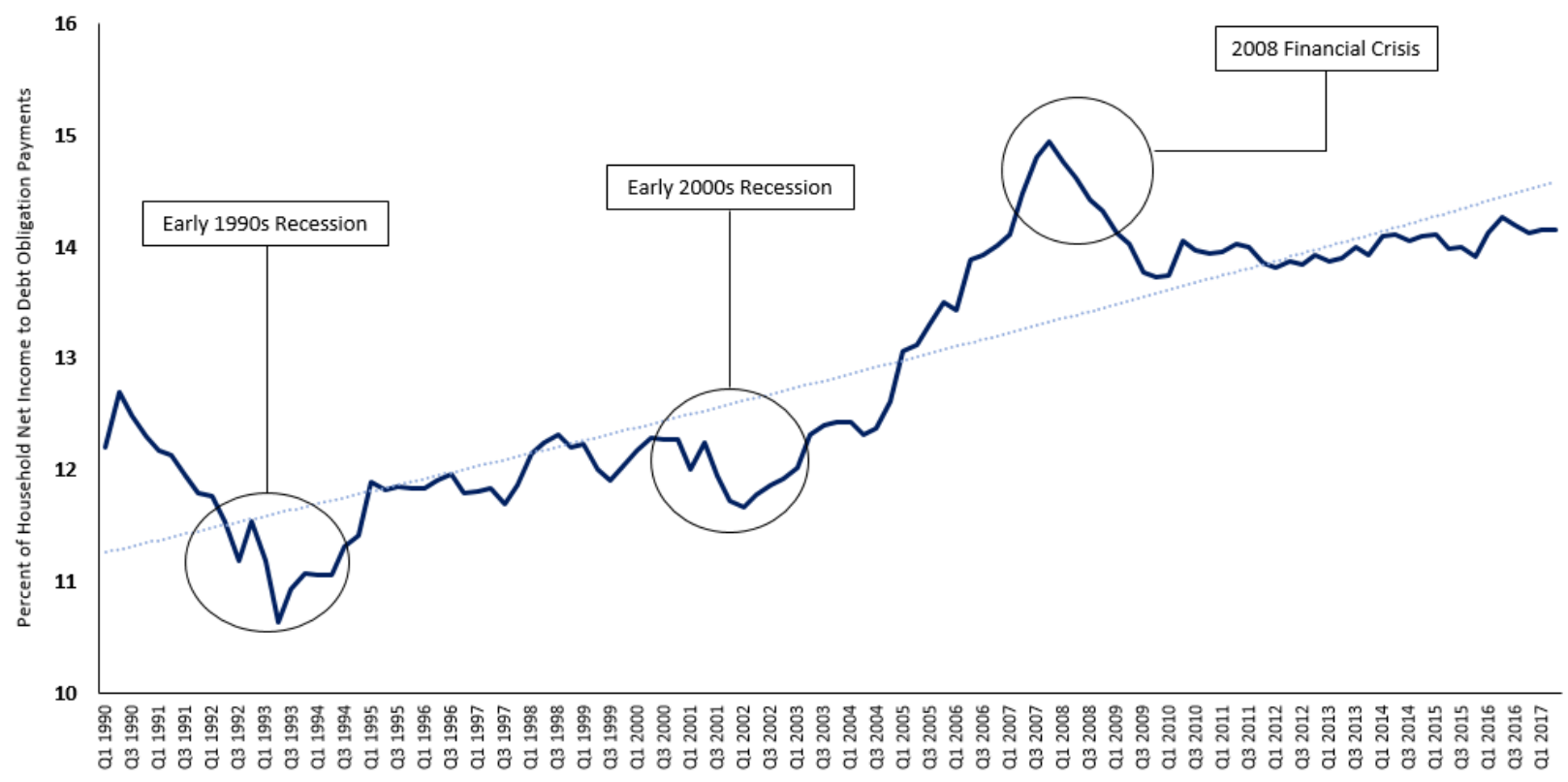


Appendix 7 - Canadian Residential Mortgage Lending by Institution 2015

Canadian Residential Mortgage Lending by Institution - 2015

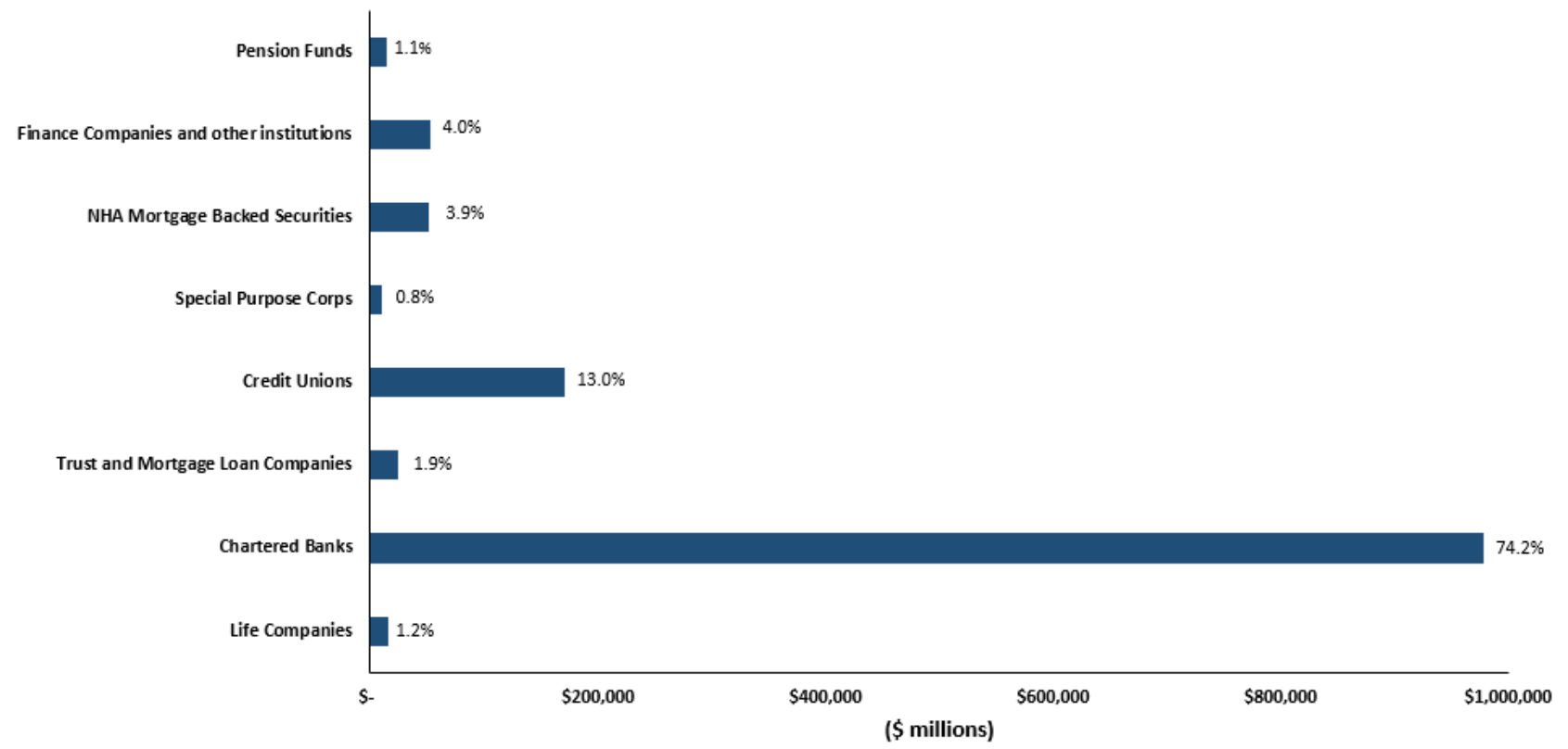

Appendix 8 - Real Estate and Rental and Leasing to Canadian GDP 2009-2017

Real Estate and Rental and Leasing to Canadian GDP 2009 - 2017

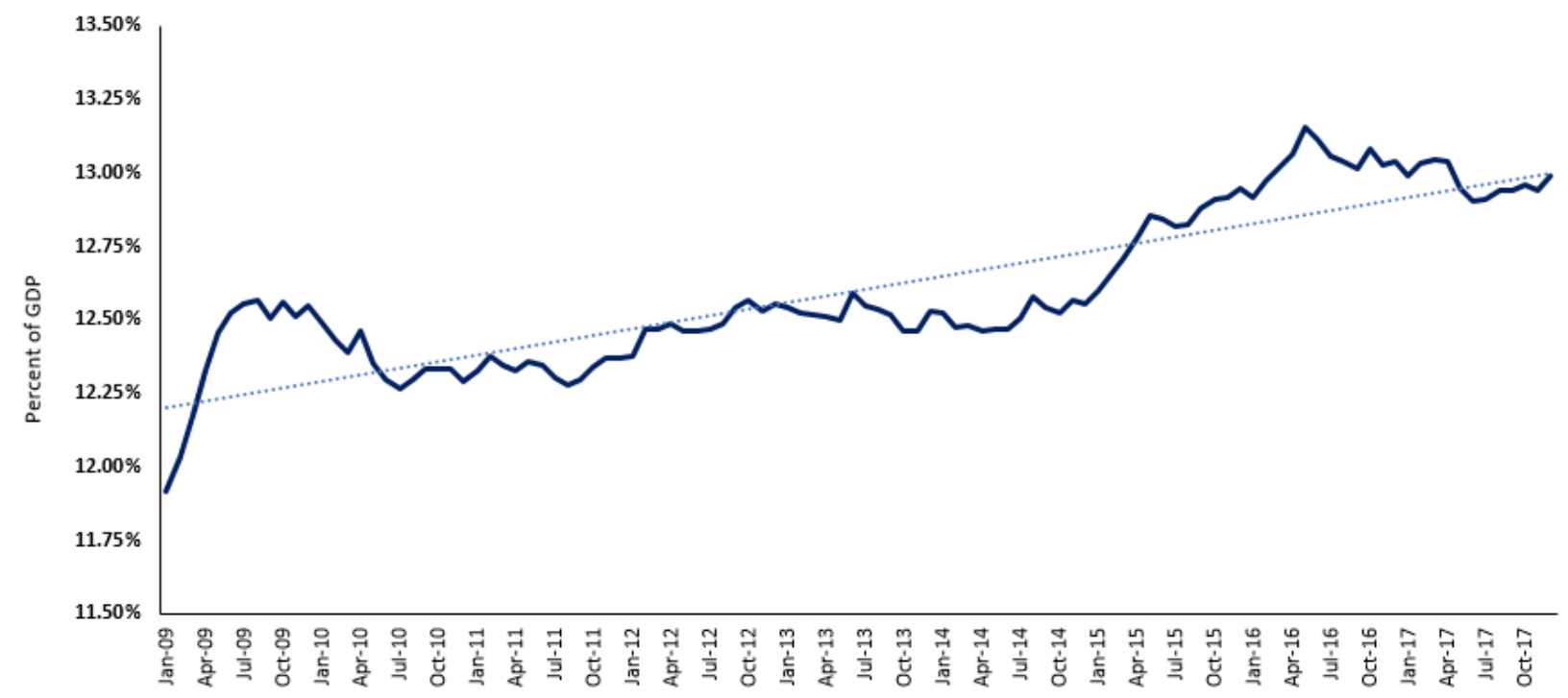

